\title{
IMPLIKASI PROGRAM PARENTING TERHADAP \\ PENDIDIKAN KARAKTER ANAK
}

\author{
Ni Ketut Murdiani \\ Widya Darshan Yoga Center, Denpasar \\ Email: ketutmurdiani021293@gmail.com
}

Abstract:

Education is a lifelong learning process that can be characterized by changes in behavior. The learning process in the learner and the results obtained are the ability to adjust to the environment and fulfillment of needs. Education can be held on formal, informal and non-formal channels. This form of education does not seem to be able to make character of the students. Formal education tends to emphasize cognitive aspects only. While informal and non-formal education is not able to provide an example to children so that they are not optimally developed psychologically. Especially education obtained from parents. Here the cause may lie in the lack of knowledge of parents about how to educate children well. On this basis it is very important that there is a parenting program in elementary schools. With the parenting program, parents will be able to educate and care for children properly and correctly so that children can become noble characters. This parenting program usually affects parents in their knowledge of how to educate properly, and has a great influence on the character of the child.

Keywords: Parenting, Character Education, Parents

\section{Abstrak:}

Pendidikan merupakan proses belajar sepanjang hayat yang dapat ditandai dengan adanya perubahan tingkah laku. Proses belajar pada diri pembelajar dan hasil yang diperoleh adalah kemampuan menyesuaikan diri dengan lingkungan dan pemenuhan atas kebutuhan. Pendidikan dapat diselenggarakan pada jalur formal, informal dan non formal. Bentuk pendidikan tersebut sepertinya belum mampu menjadikan peserta didik berkarakter. Pendidikan formal lebih condong menekankan aspek kognitif saja. Sementara pendidikan informal dan non formal tidak mampu memberikan teladan kepada anak sehingga mereka tidak maksimal berkembang secara kejiwaan. Terutama pendidikan yang didapatkan dari orang tua. Disini penyebabnya mungkin terpetak pada minimnya penetahuan orang tua mengenai cara mendidik anak secara baik. Atas dasar itu penting sekali adanya program parenting di sekolah dasar. Dengan adanya program parenting, para orang tua akan mampu mendidik dan mengasuh anak dengan baik dan benar sehingga anak bisa menjadi berkarakter mulia. Program parenting ini biasanya berpengaruh pada orang tua dalam pengetahuannya bagaimana cara mendidik dengan benar, serta sangat berpengaruh pada karakter anak.

Kata kunci: Parenting, Pendidikan Karakter, Orang Tua

\section{Pendahuluan}

Pendidikan pada hakikatnya upaya menanamkan nilai pada individu dan mengembangkan potensi kebernilaian individu atau kelompok ke arah kematangan. Pendidikan adalah proses belajar sepanjang hayat yang dapat 
ditandai dengan adanya perubahan tingkah laku. Proses belajar pada diri pembelajar dan hasil yang di peroleh adalah kemampuan menyesuaikan diri dengan lingkungan dan pemenuhan atas kebutuhan. Pendidikan dapat diselenggarakan pada jalur pendidikan formal, jalur pendidikan informal dan jalur pendidikan non formal. Untuk jalur pendidikan formal, pendidikan dilaksanakan di sekolah dalam bentuk kegiatan belajar mengajar, secara berjenjang dan berkesinambungan. Adapun jenjang pendidikan yang dimaksud terdiri atas pendidikan anak usia dini (PAUD), pendidikan dasar (SD) pendidikan menengah pertama (SMP), pendidikan menengah atas (SMA/SMK) dan pendidikan tinggi (D1-S3). Dari kelima tahapan pendidikan pada jalur ini, pendidikan karakter pada peserta didik khususnya pada tahapan sekolah dasar (SD) menjadi sangat utama, yang artinya menjadi ujung tombak utama dalam menentukan dan membentuk karakter peserta didik sebelum menempuh tahapan pendidikan selanjutnya. Dimana seperti yang kita ketahui, usia peserta didik pada sekolah dasar adalah berkisar antara 7 tahun - 12 tahun, dimana usia ini adalah usia yang sangat strategis, mengingat perkembangan fisik, mental dan psikologis siswa bertumbuh cepat, dinamis dan mengakar.

Pendidikan karakter adalah suatu yang penting dalam membangun kembali peradaban bangsa. Banyak bangsa yang maju di dunia yang berwal dari karakter unggul yang dimiliki warganya. Bangsa yang ingin maju, berdaulat dan sejahtra membutuhkan karakter yang kuat. Kesejahtraan sebuah bangsa bermula dari karakter kuat warganya (Marcus Tutillus 106-43 SM). Kemajuan suatu bangsa tidak hanya ditentukan oleh kekayaan sumber alam, kompetensi, dan kecanggihan teknologi tetapi yang utama dan terutamanya adalah karena dorongan semangat dan karakter bangsanya. Pentingnya pendidikan karakter bagi bangsa Indonesia adalah sebagai modal dasar untuk melaksanakan pembangunan di segala bidang dalam rangka menuju persaingan di era abad 21. Dalam pembentukan karakter harus mulai dari membangun nilai-nilai spritual, mengasah dan membangkitkan kecerdasan emosional dan kecerdasan intelektual yang sudah diberikan Tuhan sebagai Fitrah manusia sejak lahir melalui pendidikan yang utuh dan menyeluruh. Dalam prosesnya sendiri fitrah yang alamiah ini berupa potensi pemberian Tuhan sangat dipengaruhi beberapa faktor mulai dari lingkungan, keluarga, lingkungan pendidikan dan lingkungan masyarakat. Maka sangat penting adanya sinergitas dan keutuhan dari Tri Pusat pendidikan dalam membentuk anak Indonesia yang cerdas, handal, bedaya saing dan berkarakter unggul. Jadi pendidikan karakter bukan hanya tugas guru di sekolah tetapi merupakan tanggung jawab elemen bangsa.

Pendidikan karakter harus dilaksanakan sejak anak usia dini karena usia dini merupakan periode perkembangan yang sangat penting dalam kehidupan manusia. Pada masa ini, seluruh instrumen besar manusia terbentuk, bukan kecerdasan saja tetapi seluruh kecakapan psikis. Para ahli menanamkan periode ini sebagai usia emas perkembangan. Pendidikan anak usia dini sangat penting karena menentukan kualitas SDM di masa depan. Hal ini disebabkan karena masa pembentukan otak manusia terjadi paling cepat pada usia saat anak berada pada usia dini. Oleh sebab itu pendidikan karakter mutlak menjadi hal yang sangat penting untuk pada siswa, sebagai dasar pengembangan dan penguatan dasar yang bernilai positif atas nilai kognitif, afektif dan psikomorik. Pendidikan karakter dapat dimaknai sebagai pendidikan nilai, pendidikan budi pekerti, pendidikan moral, pendidikan watak, yang bertujuan mengembangkan kemampuan peserta didik untuk memberikan keputusan baik buruk, memelihara apa yang baik, mewujudkan dan menebar kebaikan itu dalam kehidupan sehari-hari dengan sepenuh hati. Pendidikan karakter juga dapat di definisikan sebagai pendidikan menanamkan dan mengembangkan 
karakter-karakter luhur itu, menerapkan dan mempraktekkan dalam kehidupannya baik dalam keluarga, sebagai anggota masyarakat dan warga negara ( Agus Wibowo, 2012).

Pendidikan karakter pada usia anak sekolah dasar merupakan isu krusial yang sedang marak diperbincangkan. Melihat data yang terjadi dilapangan, menunjukkan ada peningkatan kasus kekerasan ataupun tindakan asusila maupun kekerasan psikis dalam bentuk bully yang dilakukan oleh anak sekolah dasar secara masif. Hal ini sangat memprihatinkan dan harus menjadi perhatian serius, tidak hanya oleh Pemerintah tetapi juga oleh seluruh anggota masyarakat, tidak terkecuali pihak orang tua/ wali siswa yang berkomitmen untuk bekerjasama dengan pihak sekolah untuk secara aktif mengantisipasi fenomena ini. Pada akhirnya inilah alasan utama mengapa kegiatan parenting yang difasilitasi oleh sekolah dengan serangkaian program-programnya menjadi prioritas untuk diangkat dan diteliti lebih jauh, sebab peserta didik pada tahapan ini cenderung meniru, memanipulatif hal ataupun orang yang dekat dengan lingkungan sekitarnya, untuk kemudian dilakukan secara berulang dan pada akhirnya menjadi habbit atau kebiasaan menetap, yang belakangan dinamai dengan bad character dan good character

Kelompok sekolah dasar merupakan kelompok yang sangat strategis dan efektif dalam pembinaan karakter ini , hal menjadi kesadaran kolektif dan seluruh elemen bangsa ini. Karena pertama, masalah pendidikan karakter anak sekolah dasar yang belum dapat mengakses pendidikan karakter. Kedua, kurangnya pemahamna para guru akan hakekat tujuan pendidikan nasional untuk membangun peserta didik menjadi manusia yang berkarakter. Sehingga dalam proses pembelajaran terlalu menitik beratkan pada aspek kognitif. Padahal amanat Undang-Undang sudah jelas bahwa tujuan pendidikan nasional adalah untuk membentuk (peserta didik) menjadi manusia holistik dan berkarakter. Akibat dari kekurang pahaman ini banyak praktek-praktek pembelajaran disekolah dasar yang cendrung lebih mementingkan kemampuan akademik (calistung) daripada pengembangan aspek emosi dan sosial anak. Hal ini tidak terlepas dari tuntutan orang tua, termasuk Sekolah Dasar yang mensyaratkan penerimaan siswa dengan melakukan tes kemampuan calistung. Memaksakan anak usia di bawah 7 tahun untuk belajar calistung akan beresiko timbulnya stress jangka panjang, (Elkind,2000:12). Praktek seperti ini jelas akan menghambat pembentukan karakter anak. Ketiga kurangnya wawasan guru tentang pendekatan dan metode pendidikan karakter yang tepat dalam pembentukan karakter anak usia dini. Padahal wawasan guru dan berbagai pendekatan dan metode tersebut sangat penting dalam implementasi pendidikan karakter. Akibat kurangnya wawasan guru dalam hal model, pendekatan, metode pembelajaran pendidikan karakter di SD, maka proses pembelajaran akan menjadi pasif dan tidak memberikan pengalaman kongkrit pada anak. ( Megawangi. 2011:61).

Melihat lebih jauh, di Indonesia saat ini, kasus kenakalan remaja yang menjadi sorotan publik adalah tawuran antar pelajar, membolos dari jam sekolah, penggunaan narkotika, seks bebas, bullying, haters, pornografi, pencurian, penganiayaan bahkan sampai pembunuhan. Pelakunya tidak hanya berasal dari peserta didik pada SMP dan SMA/SMK tetapi juga peserta didik SD. Seperti yang terjadi pada tahun 2018 lalu di Kediri, yang diberitakan oleh media TV, telah terjadi kasus penganiayaan oleh siswa SD berinisial $\mathrm{T}$ (12 thn) kepada teman sebayanya hanya karena kesalahan gol bunuh diri pada permainan bola bersama teman-teman lainnya, sehingga korban mengalami kritis dan harus menjalani perawatan intensif di Rumah Sakit. Kasus terbaru, seorang pelajar SD juga menjadi korban pemerkosaan oleh sekelompok remaja di bawah umur, hingga korban harus mengalami 
trauma dan membutuhkan bantuan tenaga psikiatri selain luka-luka akibat luka fisik.

Tentu menjadi pertanyaan kita bersama, mengapa kasus tersebut dapat terjadi ? banyak faktor yang mempengaruhi, baik dari internal pelaku maupun eksternal pelaku. Namun, melihat dari usia pelaku yang masih dibawah umur, tentu hal ini dikarenakan akibat kesalahan pola asuh. Pola asuh orang tua yang kurang tepat, memberikan resiko perilaku menyimpang anak di masa depan. Faktor orang tua yang terlalu sibuk dengan pekerjaan, hobby, kondisi keluarga yang broken home, kebebasan yang tidak bertanggung jawab, ketidakdisiplinan, kemanjaan dan banyak hal lain yang "memaksa" orang tua untuk menyerahkan begitu saja tanggung jawab pola pengasuhan anak kepada pihak sekolah tanpa turut memperhatikan perkembangan anak masing-masing. Sedangkan, penguatan karakter mesti dilaksanakan secara terpadu yakni antara pihak sekolah dan pihak wali siswa terutama orang tua siswa. Maka dari itu, pihak Sekolah Dasar harus lebih bersungguhsungguh dalam melihat peluang-peluang ini dengan lebih serius menggarap program parenting pada siswa di sekolahnya masing-masing dengan melibatkan wali siswa yang bersangkutan.

Adapun salah satu solusi yakni kegiatan yang dapat membantu anak menjadi anak yang berkarakter unggul yaitu dengan cara mengadakan kegiatan Parenting di sekolah. Kegiatan parenting yang merupakan perwujudan pendidikan karakter, kegiatan parenting ini adalah suatu kegiatan yang diadakan di sekolah yang bertujuan untuk menjalani hubungan yang baik antara guru dengan orang tua, dengan agenda kegiatan berupa pemberian wawasan, arahan dan pengetahuan tentang bagaimana mendidik anak agar anak tersebut menjadi lebih berkarakter mulia. Anak tersebut tidak hanya melaksanakan kegiatan akademis saja atau lebih mementingkan aspek pengetahuan namun aspek kognitifnya juga harus dikembangkan dengan baik.
Dengan menggunakan cara Parenting, untuk mewujudkan prinsip bahwa mendidik anak tidak hanya di sekolah, tetapi juga perlu adanya sinergitas dengan wali siswa, terutama dengan tidak adanya kekerasan pola asuh pada anak, pemanfaatan waktu yang berkualitas untuk anak, dan usaha segenap pihak untuk mendukung kegiatan parenting ini menjadi tonggak menjawab tantangan zaman milenial saat ini secara nyata. Adapun manfaat dari kegiatan parenting tersebut diantaranya Kegiatan parenting akan menjadi suatu wadah yang dapat memberikan keuntungan pada semua pihak, baik kepada orang tua, kelompok bermain, maupun pemerintah.

\section{Pembahasan}

\section{Pengaruh Program Parenting Terhadap Pengetahuan Orang Tua}

Kegiatan parenting/Program di SD berbasis keluarga merupakan Program dukungan yang ditujukan kepada para orang tua atau anggota keluarga lain agar semakin memiliki kemampuan dalam mengasuh, merawat, melindungi dan mendidik anaknya dirumah sehingga anak dapat tumbuh dan berkembang secara optimal sesuai usia dan tahap perkembangannya. Program ini dilakukan untuk menyelaraskan kegiatan-kegiatan pendidikan anak dilembaga pendidikan dengan di rumah. Parenting education merupakan bentuk intervensi yang diberikan pada responden. dikemas dalam bentuk pelatihan, dengan menggunakan tema yang berbeda-beda yang diberikan kepada orang tua dalam memenuhi kebutuhan dasar anak usia dini untuk proses tumbuh kembang. Menurut Priyatna (2010) mengartikan pelatihan adalah suatu proses pendidikan jangka pendek yang menggunakan cara dan prosedur yang sistematis dan terorganisir. Para peserta pelatihan akan mempelajari pengetahuan dan ketrampilan yang sifatnya praktis untuk tujuan tertentu. Sedangkan menurut Notoatmodjo (2003) Pelatihan adalah bagian pendidikan yang menyangkut proses belajar untuk memperoleh dan meningkatkan 
ketrampilan diluar sistem pendidikan yang berlaku dalam waktu yang relatif singkat dan dengan metoda yang lebih mengutamakan praktek dari teori. Pada umumnya pelatihan ini diperuntukkan sasaran pendidikan yang sudah dewasa dalam rangka mempersiapkan mereka untuk memasuki lapangan kerja. Oleh karena itu pelatihan juga merupakan salah satu bentuk pendidikan orang dewasa, yang mampu merubah perilaku seseorang meliputi pengetahuan, sikap dan ketrampilan.

Menurut Notoatmodjo, 2007 Pengetahuan adalah merupakan hasil "tahu" dan ini terjadi setelah orang mengadakan penginderaan terhadap suatu objek tertentu. Penginderaan terhadap obyek terjadi melalui panca indra manusia yakni penglihatan, pendengaran, penciuman, rasa dan raba dengan sendiri. Pelatihan program parenting dapat berpengaruh terhadap pengetahuan responden dimungkinkan dapat dipengaruhi oleh faktor bisa dari proses pelatihan itu sendiri, bisa juga dari individu peserta pelatihan. Dari faktor pelatihan kemungkinan disebabkan karena: 1) Tempat pelaksanaan Pelatihan dilaksanakan di Centre yang berada di sekolah Sathya Sai dengan ruangan yang cukup luas, bersih, tenang dan nyaman. Kondisi ini cukup kondusif, dapat memberikan rasa aman dan nyaman peserta pelatihan sehingga dapat berkonsentrasi dan antusias dalam mengikuti kegiatan. Keadaan ini memudahkan peserta pelatihan menangkap/ memahami materi yang diberikan, 2) Metode yang digunakan dalam kegitan pelatihan parenting meliputi saling menyampaikan pendapatnya, diskusi kelompok, simulasi dan demonstrasi. Metode tersebut biasa digunakan pada pelatihan partisipatori. Metode ini dapat mengaktifkan peserta latihan untuk berperan serta secara aktif dalam kegiatan pelatihan.

Peserta pelatihan dapat leluasa saling memberi dan menerima pengalaman-pengalaman yang dimiliki sesuai tema yang sedang dibahas. Menurut Notoatmodjo (2003) pemilihan dan penggunaan metode-metode yang tepat sesuai dengan situasi dan kondisi dalam kegiatan pelatihan mampu untuk memperbaiki keseluruhan proses pembelajaran baik cara belajar, mengajar, cara berinteraksi diantara fasilitator dan peserta pelatihan dsb. Dengan menerapkan metode afektif pada peserta pelatihan, maka peserta pelatihan yang memiliki minat belajar dan sikap positif terhadap topik yang akan dibahas maka akan membuat peserta pelatihan merasa senang mempelajarinya, sehingga dapat mencapai hasil pembelajaran yang optimal. Pada waktu pengindraan sampai menghasilkan pengetahuan tersebut sangat dipengaruhi oleh intensitas perhatian persepsi terhadap obyek. Sebagian besar pengetahuan manusia diperoleh melalui mata dan telinga. Selain dari faktor proses pelatihan, karakteristik responden juga dapat berpengaruh antara lain: 1) Usia mempengaruhi terhadap daya tangkap dan pola pikir seseorang. Semakin bertambah usia akan semakin berkembang pula daya tangkap dan pola pikirnya, sehingga pengetahuan yang diperolehnya semakin membaik. Pada usia madya, individu akan lebih berperan aktif dalam masyarakat dan kehidupan sosial serta lebih banyak melakukan persiapan demi suksesnya upaya menyesuaikan diri menuju usia tua, selain itu orang usia madya akan lebih banyak menggunakan banyak waktu untuk membaca. Kemampuan intelektual, pemecahan masalah, dan kemampuan verbal dilaporkan hampir tidak ada penurunan pada usia ini. Alasan ini sesuai dengan usia responden yang mayoritas adalah kelompok usia madya. 2) Pendidikan. Pendidikan adalah suatu usaha untuk mengembangkan kepribadian dan kemampuan di dalam dan di luar sekolah dan berlangsung seumur hidup.

Pengetahuan sangat erat kaitannya dengan pendidikan dimana diharapkan seseorang dengan pendidikan tinggi, maka orang tersebut akan semakin luas pula pengetahuannya. Namun perlu ditekankan bahwa seorang yang berpendidikan rendah tidak berarti mutlak berpengetahuan rendah pula. Pengetahuan tidak mutlak diperoleh di 
pendidikan formal, akan tetapi juga dapat diperoleh pada pendidikan non formal. Pengetahuan seseorang tentang sesuatu obyek juga mengandung dua aspek yaitu aspek positif dan negatif. Kedua aspek inilah yang akhirnya akan menentukan sikap seseorang terhadap obyek tertentu. Semakin banyak aspek positif dari obyek yang diketahui, akan menumbuhkan sikap makin positif terhadap obyek tersebut. 3) Informasi yang diperoleh baik dari pendidikan formal maupun non formal dapat memberikan pengaruh jangka pendek (immediate impact) sehingga menghasilkan perubahan atau peningkatan pengetahuan. Majunya teknologi akan tersedia bermacam-macam media massa yang dapat mempengaruhi pengetahuan masyarakat tentang inovasi baru. Sebagai sarana komunikasi, berbagai bentuk media massa seperti televisi, radio, surat kabar, majalah, dan lain-lain mempunyai pengaruh besar terhadap pembentukan opini dan kepercayan orang.

\section{Pengaruh Program Parenting Terhadap Sikap Anak}

Sikap merupakan suatu kencenderungan untuk bertindak secara suka atau tidak suka terhadap suatu objek. Sikap dapat dibentuk melalui cara mengamati dan menirukan sesuatu yang positif, kemudian melalui penguatan serta menerima informasi verbal. Perubahan sikap dapat diamati dalam proses pembelajaran, tujuan yang ingin dicapai, keteguhan, dan konsistensi terhadap sesuatu. Fenomena sikap yang timbul tidak saja ditentukan oleh keadaan objek yang sedang dihadapi tetapi juga ada kaitannya dengan pengalaman-pengalaman masa lalu, oleh situasi di saat sekarang, dan oleh harapan-harapan untuk masa yang akan datang. Sikap manusia, atau untuk singkatnya disebut sikap, telah didefinisikan dalam berbagai versi oleh para ahli (Azwar, 2007). Selanjutnya Azwar (2007) menyimpulkan bahwa faktor-faktor yang mempengaruhi pembentukan sikap adalah pengalaman pribadi, kebudayaan, orang lain yang dianggap penting, media massa, institusi atau lembaga pendidikan dan lembaga agama, serta faktor emosi dalam diri individu.

\section{Pengalaman Pribadi}

Untuk dapat menjadi dasar pembentukan sikap, pengalaman pribadi harus meninggalkan kesan yang kuat. Karena itu, sikap akan lebih mudah terbentuk apabila pengalaman pribadi tersebut melibatkan faktor emosional. Dalam situasi yang melibatkan emosi, penghayatan akan pengalaman, akan lebih mendalam dan lebih lama berbekas. Pengalaman yang dimiliki oleh seseorang dengan suatu objek psikologis, cenderung akan membentuk sikap negatif terhadap objek tersebut. Sikap akan lebih mudah terbentuk jika yang dialami seseorang terjadi dalam situasi yang melibatkan faktor emosional. Situasi yang melibatkan emosi akan menghasilkan pengalaman yang lebih mendalam dan lebih lama membekas. Dalam pengasuhan anak orang tua memiliki variasi yang berbeda-beda dengan adanya pola asuh yang bervariasi anak akan tau bagaimana bersikap yang baik dari pengalaman yang didapatnya. Pada dasarnya anak-anak tersebut semua tinggal bersama orang tua, sehingga semua kebutuhan dan perawatan anak menjadi tanggung jawab orang tua. Keterlibatan orang tua adalah suatu keniscayaan bahwa orang tua adalah guru pertama dari anak-anaknya. Apabila anak telah masuk sekolah orang tua adalah mitra kerja yang utama bagi guru anaknya bahkan sebagai orang tua, mereka mempunyai berbagai pilihan yaitu orang tua sebagai pelajar, orang tua sebagai relawan, orang tua sebagai pembuat keputusan, orang tua sebagai tim kerjasama antara orang tua dan guru. Dalam peran-peran tersebut peran orang tua membantu anak untuk mengubah sikap anak menjadi yang lebih baik dan dapat membantu meningkatkan perkembangan dan pertumbuhan anak. 


\section{Orang Lain Yang Dianggap Penting}

Pada umumnya, individu bersikapkonformis atau searah dengan sikap orang orang yang dianggapnya penting. Kecenderungan ini antara lain dimotivasi oleh keinginan untuk berafiliasi dan keinginan untuk menghindari konflik dengan orang yang dianggap penting tersebut. Data hasil penelitian menunjukkan bahwa orang yang dominan dalam mengambil keputusan adalah ibu dan ayah. Sesuai adat budaya jawa orang tua itu harus dihormati dan dituruti nasehatnya dan selalu ikut berperan dalam urusan rumah tangga, terutama berkaitan dengan masalah mendidik anak. Menurut pendapat Burrhus Frederic Skinner, seperti yang dikutip Azwar sangat menekankan pengaruh lingkungan (termasuk kebudayaan) dalam membentuk pribadi seseorang. Kepribadian merupakan pola perilaku yang konsisten yang menggambarkan sejarah penguat (reinforcement) yang kita alami. Kebudayaan juga akan memberikan corak pengalaman bagi individu dalam suatu masyarakat. Kebudayaan telah menanamkan garis pengarah sikap individu terhadap berbagai masalah.

\section{Implikasi Program Parenting terhadap Pendidikan karakter Anak}

Menurut Kamus Besar Bahasa Indonesia (KBBI) arti kata implikasi adalah keterlibatan atau keadaan terlibat. Sehingga setiap kata imbuhan dari implikasi seperti kata berimplikasi atau mengimplikasikan yaitu berarti mempunyai hubungan keterlibatkan atau melibatkan dengan suatu hal. Kata implikasi memiliki persamaan kata yang cukup beragam, diantaranya adalah keterkaitan, keterlibatan, efek, sangkutan, asosiasi, akibat, konotasi, maksud, siratan, dan sugesti. Persamaan kata implikasi tersebut biasanya lebih umum digunakan dalam percakapan sehari-hari. Hal ini karena kata implikasi lebih umum atau cocok digunakan dalam konteks percakapan bahasa ilmiah dan penelitian. Implikasi kegiatan parenting ini sangat besar pengaruhnya terhadap pendidikan karakter anak karena dalam kegiatan parenting tidak hanya memberikan pengarahan dengan orang tua melainkan untuk bisa membentuk karakter anak yang mulia. Kegiatan parenting ini juga dapat mensinkronkan hubungan antara orang tua dengan guru, pembentukan karakter yang mulia itu diawali dengan pendidikan yang diberikan oleh orang tua yang paling pertama dan utama mulai dari dalam kandungan.

Pendidikan karakter menurut Kerta Jaya adalah ciri khas yang dimiliki oleh suatu benda atau individu. Ciri khas tersebut adalah asli dan mengakar pada kepribadian benda atau individu tersebut, serta merupakan "mesin" yang mendorong bagaimana seseorang bertindak, bersikap, berucap dan merespon sesuatu. Pendidikan karakter menurut kamus Psikologi, karakter adalah kepribadian di tinjau dari titik tolak etis atau moral, misalny kejujuran seseorang, dan biasanya berkaitan dengan sifat-sifat yang relatif tetap. Pendidikan karakter pada anak sekolah dasar dewasa ini sangat diperlukan dikarenakan saat ini bangsa Indonesia mengalami krisis karakter dan degradasi moral dalam diri anak. Karakter yang dimaksud adalah watak, tabiat,akhlak atau kepribadian seseorang yang terbentuk dari hasil internalisasi berbagai kebajikan yang diyakini dan digunakan sebagai landasan untuk cara pandang, berpikir, bersikap dan bertindak. Dengan berbagai masalah yang melanda bangsa Indonesia maka pendidikan karakter sangat penting dilakukan mulai dari dalam kandungan pengembangan pendidikan itu harus dilakukan karena anak yang belum lahir ia bisa merespon apa yang kita kerjakan.

Dalam proses pembentukan karakter tentunya berawal dari orang tua itu sendiri karena keluarga merupakan pendidikan yang pertama dan utama bagi anak merupakan tempat pertama kalinya 
anak-anak memperoleh pendidikan dan pengajaran dari orang tua. Mulai dari belajar bercakap-cakap, mengenal nama anggota badan anggota keluarga, nama warna, penanaman disiplin tentang makan, tidur, dan sebagainya. Keluarga juga memiliki fungsi yang sangat unik, dinamis, memilki pesan sosial, pendidikan sekaligus peran keagamaan. Seorang anak sebelum mengenal masyarakat lebih luar serta mendapat bimbingan dari sekolah anak tersebut pertama kali mendapat pendidikan dari orang tuanya baik pendidikan yang akademis serta penanama karakter yang mulia.

Lickona (2012: 81) menegaskan keluarga sebagai pendidik karakter yang paling utama. Keluarga pihak pertama yang paling penting dalam memengaruhi karakter anak. Tugas sekolah adalah memperkuat tugas positif (etos kerja, rasa hormat, tanggung, jawab, jujur dan lain-lain) yang diajakarkan di rumah. Kenyataannya, tentu saja ini sering terjadi malah sebaliknya banyak orang tua tidak memenuhi aturan peran penting sebagai pendidik dalam membentuk karakter anak. Dalam mendidik anak tentunya orang tualah yang berperan penting maka dari itu sebagai orang tua agar bisa mendidik, mengasuh, dan membuat anak tersebut menjadi anak yang berkarakter mulia.

\section{Kegiatan Parenting di Sekolah Dasar}

Kegiatan parenting ini adalah sebagai proses interaksi berkelanjutan antara orang tua dan anakanak mereka yang meliputi aktivitas-aktivitas sebagai berikut: memberi makan (nourishing), memberi petunjuk (guiding), dan melindungi (protecting) anak-anak ketika mereka tumbuh berkembang. Penggunaan kata parenting untuk aktivitas-aktivitas orang tua dan anak di sini karena sampai saat ini belum ada padanan kata dalam bahasa Indonesia yang tepat.

Keluarga sebagai unit terkecil di masyarakat yang terbentuk atas dasar komitmen untuk mewujudkan fungsi keluarga khususnya fungsi sosial dan fungsi pendidikan, harus benarbenar dioptimalkan sebagai mitra lembaga SD. Oleh karena itu melalui program parenting sebagai wadah komonikasi antara orang tua, di samping untuk memberikan sosialisasi terhadap program-program yang diselenggarakan oleh lembaga SD. Secara umum tujuan program parenting adalah mengajak para orang tua untuk bersama-sama memberikan yang terbaik buat anak-anak mereka. Sedangkan secara khusus tujuan pengembangan program kegiatan parenting adalah meningkatkan pengetahuan keterampilan orang tua dalam melaksanakan perawatan, pengasuhan, dan pendidikan anak di dalam keluarga sendiri dengan landasan dasar-dasar karakter yang baik. Mempertemukan kepentingan dan keinginan antara pihak keluarga dan sekolah guna mensinkronkan keduanya hingga pendidikan karakter yang di kembangkan di lembaga SD dapat ditindak lnjuti di lingkungan keluarga. Menghubungakan antara program sekolah dengan program rumah. Lembaga $\mathrm{Sd}$ yang memiliki program-program kelembagaan dan pembelajaran kadang kala bertentangan atau tidak selaras dengan kebiasaan-kebiasaan yang terjadi di lingkungan keluarga. Dengan program parenting ini akan terjadi keselarasan dan keterkaitan, kerjasama, yang saling mendukung, dan saling menguatkan

Secara bahasa parenting berasal dari bahasa inggris, dari kata Parent yang berarti orang tua. Sedangkan dalam kamus oxford,parenting adalah the process of caring for your child or children. Takdir ilahi dalam buku"quantum parenting" ia memaknai parenting dengan sebuah proses memanfaatkan keterampilan mengasuh anak yang di landasi oleh aturan-aturan yang agung dan mulia. Pola asuh merupakan merupakan bagian dari proses pemeliharaan anak dengan menggunakan teknit dan metode yang menitik beratkan pada kasih sayang dan ketulusan cinta 
yang mendalam dari orang tua. Berdasarkan hasil seminar di north Carolina menurut Debord, dkk dengan tema :Creative Approaches to Parenting Education, menjelaskan bahwa : "The family, not the school, provides the first educational experiences begining in infancy, with the attempt to guide and direct the child-to train him." Artinya :Keluarga bukan sekolah, memberikan pengalaman-pengalaman pendidikan yang pertama mulai pada masa pertumbuhan dengan usaha-usaha untuk membimbing dan mengarahkan anak serta melatihnya. Dengan adanya kegiatan parenting tersebut pengetahuan orang tua dalam mendidik dan mengasuh anak yang baik akan bertambah. Dengan mendapat kegiaan parenting orang tua akan lebih bisa mengontrol dirinya denga baik jadi jika orang tua dapat mengontrol emosinya dengan baik maka dalam mendidik anak lebih bisa bersabar dan tidak dengan kekerasan dengan cara seperti itu maka anak akan menjadi lebih dapat bertujuan untuk menyelaraskan antara pendidikan yang di dapatkan di keluarga dengan pendidikan yang di dapatkan di sekolah.

Soemiarti Patmonodewo dalam sunarto meyakini bahwa keterlibatan orang tua disekolah akan meringankan guru dalam membina kepercayaan diri anak, mengurangi masalah disiplin anak, serta dapat meningkatkan motivasi anak, karena itu kegiatan program parenting dapat saling menguntungkan para orang tua dapat belajar bagaimana cara mendidik, meningkatkan pertumbuhan dan perkembangan anak. Para orang tua akan merasa lebih mampu dan dibutuhkan dalam kegiatan belajar anaknya disekolah. Selain itu orang tua mendapat kesempatan untuk mengembangkan hubungan dengan orang tua lain disekolah.

\section{Karakter Yang Dikembangkan Dalam Ke- giatan Parenting}

Kemdikbud merilis beberapa nilai-nilai pendidikan karakter yang telah teridentifikasi 18 nilai yang bersumber dari agama, Pancasila, budaya dan tujuan pendidikan nasional. Hal ini yang dikembangkan di dalam parenting sehingga para orang tua mengerti kemana arah karakter anak nantinya. Adapun ke-18 karakter tersebut diuraikan sebagai berikut:

1. Religius yaitu sikap dan prilaku yang patuh dalam melaksanakan ajaran agama yang dianutnya, toleran terhadap pelaksanaan ibadah agama lain dan hidup rukun dengan pemeluk agama lain.

2. Jujur yaitu prilaku yang di dasarkan pada upaya menjadikan dirinya sebagai orang yang selalu dapat dipercaya dalam perkataan, tindakan dan pekerjaan.

3. Toleransi yaitu sikap dan tindakan yang menghargai perbedaan agama, suku, etnis, pendapat, sikap dan tindakan orang lain yang berbeda darin dirinya.

4. Disiplin adalah tindakan yang melakukan tindakan tertib dan patuh pada berbagai ketentuan dan peraturan.

5. Kerja keras yaitu prilaku yang menunjukkan upaya sungguh-sungguh dalam mengatasi berbagai hambatan belajar dan tugas, serta menyelesaikan tugas dengan sebaikbaiknya.

6. Kreatif yaitu berpikir dan melakukan sesuatu untuk menghasilkan cara dan hasil baru dari sesuatu yang telah di miliki.

7. Mandiri yaitu sikap atau prilaku yang tidak mudah tergantung pada orang lain untuk menyelesaikan tugas-tugasnya.

8. Demokratis yaitu cara berpikir, bertindak dan bersikp yang menilai sama hak dan kewajiban dirinya dan orang lain.

9. Rasa ingin tahu yaitu sikap dan tindakan 
yang selalu berupaya untuk mengetahui lebih mendalam dan meluas dari sesuatu yang dipelajarinya.

10. Semangat kebangsaan yaitu cara berpikir, bertindak dan berwawasan yang menempatkan kepentingan bangsa dan negara di atas kepentingan diri dan kelompoknya.

11. Cinta Tanah Air yaitu cara berpikir, bersikap dab berbuat yang menunjukkan kesetiaan, kepedulian dan penghargaan yang tinggi terhadap bahasa, lingkungan fisik, social, budaya, ekonomi dan politik bangsa.

12. Menghargai prestasi sikap dan tindakan yang mendorong dirinya untuk menghasilkan sesuatu yang berguna bagi masyarakat dan mengakui serta menghormati keberhasilan orang lain.

13. Bersahabat/komonikatif yaitu tindakan yang memperlihatkan rasa senang berbicara, bergaul dan bekerja sama dengan orang lain.

14. Cinta damai yaitu sikap perkataan dan tindakan yang menybabkan orang lain merasa senang dan aman atas kehadirannya.

15. Gemar membaca yaitu kebiasaan menyediakan waktu untuk membaca berbagai macam bacaan yang memberikan kebajikan bagi dirinya.

16. Peduli lingkungan yaitu sikap dan tindakan yang selalu berupaya mencegah kerusakan pada lingkungan alam di sekitarnya, dan mengembangkan upaya-upaya untuk memperbaiki kerusakan alam yang sudah terjadi.

17. Peduli sosial yaitu sikap dan tindakan yang selalu ingin memberi bantuan kepada orang lain dan masyarakat yang membeutuhkan.

18. Tanggung jawab yaitu sikap dan prilaku seseorang untuk melaksanakan tugas dan kewajibannya yang seharusnya dia lakukan terhadap diri sendiri, masyarakat, lingkungan ( alam, sosial dan budaya)

Neagara dan Tuhan Yang Maha Esa.

\section{Simpulan}

Berdasarkan uraian diatas dapat disimpulkan bahwa pendidikan merupakan hal yang sangat penting di lakukan pada semua orang terutama pendidikan karakter harus di lakukan sedini mungkin. Pendidikan karakter harus di lakukan mulai sejak dini bahkan masih di dalam kandungan pendidikan karakter itu harus di laksanakan. Pendidikan karakter merupakan upaya perwujudan amanat Pancasila dan UUD 1945 yang dilatarbelakangi oleh munculnya permasalahan bangsa dan negara. Tujuan pendidikan karakter adalah mengembangkan karakter peserta didik agar mampu mewujudkan nilai-nilai luhur Pancasila dan berfungsi untuk mengembangkan potensi dasar, agar "berhati baik, berpikir baik dan berprilaku baik". Perbaikan prilaku yang kurang baik dan penguatan prilaku yang sudah baik, penyaring budaya yang kurang sesuai dengan nilai-nilai luhur Pancasila. Dalam membentuk karakter anak yang mulia tentunya harus ada pendidikan yang berkarakter pula maka dari itu pentingnya kegiatan parenting dalam membentuk kakarakter anak. Kegiatan parenting adalah suatu kegiatan yang melibatkan orang tua untuk mendapatkan arahan serta bimbingan yang harus dilakukan orang tua dalam mendidik anaknya dengan baik. Karakter yang harus dikembangkan dalam kegiatan karakter yaitu religius, toleransi, jujur, kerja keras, disiplin, kreatif, mandiri, demokratis, rasa ingin tahu, semangat kebangsaan, dan lainnya yang mencakup dari delapan belas karakter tersebut. 


\section{Daftar Pustaka}

Agus Wibowo. 2012. Strategi Membangun Karakter. Yogyakarta: Pustaka Pelajar.

Andri. 2010. Parenting untuk orang tua sibuk. Jakarta: PT Elek. Jakarta. Media Komputindo.

Elkind, 2000. Child Development and Education: Oxford University Press.

Lickona. 2012. Pendidikan Karakter Panduan Lengkap Mendidik Siswa Menjadi Pintar dan Baik. Bandung: Nusa Media.

Megawangi. 2011. Pendidikan Karakter. Jakarta: Indonesia Heritage Foundation.

Notoatmodjo, S. 2003. Pendidikan Dan Perilaku Kesehatan. Rineka Cipta: Jakarta.

Notoatmodjo, 2007. Promosi Kesehatan Teori dan Aplikasi, Rineka Cipta: Jakarta: Priyatna.

Saifuddin, Azwar. 1995. Sikap manusia Teori dan Pengukurannya. Yogyakarta: Pustaka Pelajar Offset.. 